\title{
PELAKSANAAN PATIENT SAFETY DALAM PROGRAM CORPORATE SOCIAL RESPONSIBILITY MELALUI BAKTI SOSIAL DI RUMAH SAKIT PREMIER JATINEGARA
}

\author{
Gerardus Gegen, Endang Wahyati Y. dan Tri Wahyu Murni \\ gerard_96@rocketmail.com \\ Magister Hukum Kesehatan \\ Universitas Katolik Soegijapranata Semarang
}

\begin{abstract}
ABSTRAK
Dalam memberikan Pelayanan kesehatan yang baik, bermutu, profesional, dan diterima pasien merupakan tujuan utama pelayanan rumah sakit, namun hal ini tidaklah mudah dilakukan mengingat pelayanan kesehatan merupakan suatu organisasi yang sangat komplek, dibutuhkan suatu pengelolaan yang baik sehingga dalam pelayanan pasien merasa terlayani dengan baik. Hal ini diatur dalam Peraturan Menteri kesehatan Nomor 1691/MENKES/PER/VII/2011 Tentang Keselamatan Pasien, dilain pihak Rumah Sakit yangg berbadan hukum PT berkewajiban melaksanakan CSR sebagai mana diatur dalam PP Nomor 47 tahun 2012 tentang tanggungjawab sosial perusahaan.

Penelitian ini mengunakan metode penelitian deskritif, dengan metode pendektan yuridis sosiologis sedangkan data yang dikumpulkan adalah berupa data primer dan data sekunder yang diperoleh melalui studi lapangan dan studi empiris, pustaka adapun analisis data dilakukan secara kualitatif.

Rumah Sakit Premier Jatinegara adalah rumah sakit swasta yang berbentuk Perseroan Terbatas melaksanakan ketentuan tentang Patient Safety dalam melakukan baksos dalam bentuk pelayanan kesehatan bagi pasien tidak mampu sebagi tanggung jawab sosial sesaui dengan ketentuan perundang-undangan antara lain UU Kesehatan, Rumah Sakit, Perseroan Terbatas dan Penanaman Modal, adapun bentuk pelaksanaan Patient Safety secara internal di lakukan melalui SK direktur tentang Patient Safety dan surat tugas pelaksanaan bakti sosial, adapun faktor-faktor yang mempengaruhi pelaksanannya antara lain: faktor yang mendukung, ketersediaan tenaga sesuai kebutuhan, visi dan misi, karena amanat Undang-Undang, Faktor yang menghambat keterbatasan dana sehinga pelaksanaan baksos hanya tindakan membutuhkan yang tidak terlalu besar, kemudian sponsor hanya diperoleh secara temporel.
\end{abstract}

Kata Kunci: Patient Safety, Corporate social Responsibility, Rumah Sakit. 


\section{LATAR BELAKANG}

Pelayanan kesehatan yang baik, bermutu, profesional, dan diterima pasien merupakan tujuan utama pelayanan rumah sakit, namun hal ini tidaklah mudah dilakukan mengingat pelayanan kesehatan merupakan suatu organisasi yang sangat komplek, dibutuhkan suatu pengelolaan yang baik sehingga dalam pelayanan pasien merasa terlayani dengan baik. Pelayanan dengan baik tentunya akan berdampak pada meningkatnya jumlah kunjungan pasien terhadap rumah sakit tersebut dan hal ini merupakan tanggung jawab rumah sakit melalui pelayanan yang diberikan terhadap pasien pasiennya, akan tetapi dalam pelaksanaan rumah sakit harus berbadan hukum yang sudah tentu tunduk pada peraturan yang berlaku oleh karena itu rumah sakit seperti kita ketahui adalah salah satu fasilitas pelayanan kesehatan yang sangat dibutuhkan dalam upaya penyelenggaraan kesehatan masyarakat dalam rangka mewujudkan masyarakat yang sehat secara fisik maupun mental.

Pengertian tentang rumah sakit dalam Undang-undang Nomor 44 tahun 2009 Tentang Rumah Sakit dapat kita lihat Pasal 1, yang menyebutkan rumah sakit adalah institusi pelayanan kesehatan yang menyelenggarakan pelayanan kesehatan perorangan secara paripurna yang menyediakan pelayanan rawat inap, rawat jalan, dan gawat darurat". Kedudukan dan fungsi rumah sakit adalah salah satu jenis sarana/fasilitas pelayanan kesehatan, yang tugas utamanya melayani kesehatan perorangan. Di samping itu rumah sakit memiliki fungsi lain yakni sebagai lembaga atau badan hukum privat sebagaimana diatur dalam Undang-Undang Rumah Sakit dan undang-undang Perseroan Terbatas. Dalam salah satu ketentuan pada Undang-Undang Rumah Sakit disebutkan bahwa rumah sakit swasta harus berbentuk PT. Konsekuensi dari ketentuan adalah bahwa Rumah Sakit harus pula tunduk pada Undang-Undang Perseroan Terbatas.

Dalam Undang-Undang PT diantaranya diatur pula bahwa kewajiban PT adalah melaksanakan fungsi CSR. Hal ini diatur lebih lanjut melalui Peraturan Pemerintah Nomor 47 Tahun 2012 Tentang Tanggung Jawab Sosial dan lingkungan Perseroan Terbatas. Pada ketentuan Pasal 2 disebutkan: "setiap perseroan terbatas selaku subyek hukum mempunyai tanggungjawab sosial dan lingkungan .maka dari ketentuan ini setiap rumah sakit swasta yang berbentuk PT pada awalnya adalah satu kegiatan penanaman modal asing atau investasi sehingga wajib melakukan perintah undang-undang yaitu melaksanan tanggung jawab sosial sebagai perseroan terbatas".

Seperti yang telah disebutkan bahwa rumah sakit merupakan perusahaan yang bergerak di bidang jasa dan sudah tentu harus tunduk pada peraturan yang berlaku yaitu Undang-Undang PT. Sebagai PT memiliki salah satu kewajiban sebagai kegiatan usaha yakni tanggugng jawab perusahaan dalam hal pelayanan terhadap lingkungan di sekitar perusahaan atau yang sering kita kenal dengan istilah corporate social responsibility.

Adapun fungsi rumah sakit sebagai fasilitas pelayanan kesehatan utamanya adalah melakukan penyelengaraan upaya kesehatan meliputi rehabilitative, prefentive, promotive, kurative, atau pelayanan paripurna, kemudian dalam menyelenggarakan upaya kesehatan mempunyai beberapa kewajiban yaitu salah satu kewajiban rumah sakit adalah menyelenggarakan pelayanan yang bermutu kemudian juga harus menghormati hak pasien seperti ; memperoleh layanan kesehatan yang manusiawi, adil, jujur, dan tanpa diskriminative serta memperoleh layanan kesehatan yang bermutu sesuai dengan standart profesi dan standart prosedur operasional sehingga memperoleh layanan kesehatan yang efektive dan efesien sehingga pasien terhindar dari kerugian fisik dan materi.

Dalam Undang-Undang Rumah Sakit Pasal 29 disebutkan salah satu kewajiban pada huruf b bahwa, "rumah sakit memiliki kewajiban memberikan pelayanan kesehatan yang aman, bermutu, anti diskriminasi dan efektif dengan mengutamakan kepentingan pasien sesuai dengan standar pelayanan rumah sakit;". Kemudian juga dalam huruf $f$ dijelaskan bahwa rumah sakit memiliki kewajiban "melaksanakan fungsi sosial antara lain dengan memberikan fasilitas pelayanan pasien tidak mampu/miskin, pelayanan gawat darurat tanpa uang muka, ambulance 
gratis, pelayanan korban bencana dan kejadian luar biasa, atau bakti sosial bagi misi kemanusiaan;".

Selanjutnya kewajiban Rumah Sakit yang lainnya dirumuskan yakni Rumah Sakit harus melaksanakan keselamatan pasien. Dalam penjelasan pasal ini diuraikan bahwa rumah sakit dibangun serta dilengkapi dengan sarana, prasarana dan peralatan yang dapat difungsikan serta dipelihara sedemikian rupa untuk mendapatkan keamanan, mencegah kebakaran, kesehatan dan keselamatan pasien, petugas, pengunjung dan lingkungan rumah sakit.

Dalam ketentuan lain rumah sakit juga mempunyai kewajiban untuk menerapakan standart keselamatan pasien seperti diatur dalam Pasal 43, yang secara keseluruhan rumusannya sebagai berikut:

(1) Rumah sakit wajib menerapkan standar keselamatan pasien.

(2) Standar keselamatan pasien sebagaimana dimaksud pada ayat (1) dilaksanakan melalui pelaporan insiden, menganalisa, dan menerapkan pemecahan masalah dalam rangka menurunkan angka kejadian yang tidak diharapkan.

(3) Rumah sakit melaporkan kegiatan sebagaimana dimaksud pada ayat (2) dibuat secara anonim dan ditujukan untuk mengkoreksi sistem dalam rangka meningkatkan keselamatan pasien.

(4) Ketentuan lebih lanjut mengenai standar keselamatan pasien sebagaimana dimaksud pada ayat (1) dan ayat (2) diatur dengan Peraturan Menteri.

Berdasarkan uraian tersebut dapat ditafsirkan bahwa Rumah Sakit Harus melaksanakan keselamatan pasien (patient safety) melalui kegiatan dengan memberikan pelayanan pasien yang lebih aman. termasuk di dalamnya penaksiran risiko, identifikasi, dan manajemen risiko terhadap pasien, pelaporan dan analisa insiden. Selanjutnya Rumah Sakit juga perlu meningkatkan kemampuan untuk belajar dan menindaklanjuti insiden, dan menerapkan solusi untuk mengurangi serta meminimalisir timbulnya risiko. Adapun yang dimaksud dengan insiden keselamatan pasien adalah kesalahan medis (medical error), kejadian yang tidak diharapkan (adverse event), dan nyaris terjadi (near miss). Ketentuan pelaksanaan sebagaimana dimaksud pada Pasal 43 ayat (4) dirumuskan melalui Peraturan Menteri kesehatan Nomor 1691/MENKES/PER/VII/2011 Tentang Keselamatan Pasien.

Berdasarkan ketentuan perundang-undangan tersebut di atas maka Rumah Sakit baik itu yang diselenggarakan oleh pemerintah maupun swasta memiliki kewajiban yang sama yakni melaksanakan patient safety. Namun demikian jika menyimak undang-undang PT, maka yang memiliki tanggung jawab sosial hanya Rumah Sakit Swasta, Karena Rumah sakit swasta merupakan badan hukum berbentuk PT, yang harus tunduk pada Undang-Undang Perseroan Terbatas.

Corporate Social Responbility (CSR) atau dalam bahasa Indonesia dapat kita sebut dengan Tanggung Jawab Sosial merupakan salah satu kewajiban hukum dari penanam modal baik dalam maupun asing. Hal ini juga harus dimaknai bukan hanya bersifat voluntary tetapi harus dilakukan sebagai mandatory dalam makna liability karena diatur di dalam perundang-undangan yaitu di dalam Undang-Undang Republik Indonesia Nomor 40 Tahun 2007 tentang Perseroan Terbatas (selanjutnya disebut Undang-Undang PT) dan Undang-Undang Republik Indonesia Nomor 25 Tahun 2007 Tentang Penanaman Modal (selanjutnya disebut Undang-Undang Penanaman Modal).

Pada ketentuan Pasal 74 Undang-Undang Perseroan Terbatas menyebutkan bahwa "setiap perseroan yang menjalankan kegiatan usahanya di bidang dan/atau berkaitan dengan sumber daya alam wajib melaksanakan tanggung jawab sosial dan lingkungan”. Selain itu aturan mengenai tanggung jawab sosial tersebut juga ditegaskan dalam Undang-Undang Penanaman Modal Pasal 15 Huruf b yaitu "setiap penanam modal berkewajiban melaksanakan tanggung 
jawab sosial perusahaan". Selanjutnya pada Pasal 34 Ayat (1) Undang-Undang Penanaman Modal diatur, "bila perseroaan tidak melaksanakan tanggung jawab sosial tersebut maka dapat dikenai sanksi mulai dari peringatan tertulis, pembatasan kegiatan usaha, pembekuan kegiatan usaha dan/atau fasilitas penanaman modal. atau pencabutan kegiatan usaha dan/atau fasilitas penanaman modal".

Rumah sakit premier jatinegara adalah rumah sakit swasta yang sudah terakreditasi nasional maupun internasional memiliki visi dan misi, untuk itu dalam rangka misi kemanusiaan tersebut maka rumah sakit premier jatinegara merupakan rumah sakit swasta yang berbadan hukum dan tunduk pada undang-undang PT karena itu harus berbentuk PT dan tunduk juga pada aturan rumah sakit karena sebagai fasilitas pelayanan kesehatan berupa rumah sakit, oleh karena itu menarik untuk dilteliti lebih lanjut tentang program CSR kaitanya dengan pateint safety dalam pelaksanaan bakti sosial sehingga peneliti mengambil judul "Pelaksanaan Pateint Safety Dalam Program CSR Melalui Bakti Sosial di Rumah Sakit Premier Jatinegara".

\section{PERUMUSAN MASALAH}

Dari uraian di atas maka yang menjadi rumusan masalah penelitian hukum ini dapat diidentifikasi masalah adalah sebagai berikut:

a. Bagaimana ketentuan hukum tentang Pateint Safety dalam pelayanan di rumah sakit?

b. Bagaimana ketentuan hukum tentang Coporate Sosial Responbility (CSR) melalui bakti sosial di rumah sakit?

c. Bagaimana pelaksanaan patient safety dalam Corporate Sosial Responbility (CSR) melalui bakti sosial di Rumah Sakit Premier Jatinegara dan faktor-faktor yang mempengaruhinya?

\section{HASIL PENELITIAN}

\section{Pelaksanaan Bakti Sosial di Rumah Sakit Premier Jatinegara}

Dalam rangka upaya melaksanakan undang-undang yang berkaitan dengan program CRS atau tanggung jawab sosial perusahaan, Rumah Sakit Premier Jatinegara melaksanakan kegiatan bakti sosial sebagai bentuk kepedulian terhadap masyarakat di sekitar rumah sakit. Bentuk kegiatan bakti sosial yang dilakukan meliputi kegiatan yang dikelola oleh Rumah Sakit sendiri maupun yang dilaksanakan melalui kerja sama dengan pihak ketiga / lembaga lain. Untuk kegiatan bakti sosial yang dikelola sendiri Rumah sakit berupa: penyuluhan kesehatan bagi masyarakat di sekitar Rumah Sakit; sunatan masal; pengobatan gratis, yang prioritas utamanya untuk masyarakat kurang mampu. Adapun kegiatan yang dilakukan melalui kerja sama dengan pihak ketiga yang dikarenakan memerlukan biaya yang cukup besar antara lain dalam bentuk operasi katarak gratis dan operasi bibir sumbing. Berdasarkan hasil wawancara kerjasama yang telah dilakukan dengan pihak ketiga dalam hal penbiayaan biasanya melibatkan pihak sponsor.

Menurut unit marketing bahwa kegiatan tersebut satu bentuk kegiatan bakti sosial yang dilakukan oleh rumah sakit Premier Jatinegra. Sebelum kegiatan bakti sosial dilakukan segala persiapan mulai dari persiapan pembentukan panitia sampai dengan perlengkapan dan pelaporan setelah kegiatan bakti sosial dilaksanakan. Kegiatan ini sudah menjadi rutinitas di Rumah Sakit maka hal tersebut tidaklah sulit dalam pelaksanaanya sebab belajar dari tahun ke tahun kegiatan ini sudah biasa.

Sesuai dengan kebijakan dan standar prosedur operasional rumah sakit Premier Jatinegara tentang CSR, maka rumah sakit terus berkomitmen untuk melaksanakan program tersebut dan akan tetap meningkatkan mutu pelayanan. 
Kegiatan bakti sosial ini dilaksanakan pertama kali dengan membentuk panitia yang dilakukan oleh unit marketing kemudian membuat pengajuan berupa proposal kegiatan dengan susunan kepanitiaan setelah itu direktur akan memgeluarkan Surat Keputusan Direktur tentang pelaksanaan program bakti sosial beserta pengaturanya tentang pelaksanaannya. Selanjutnya ketua pelaksana akan melakukan rapat dengan semua panitia dan akan melakukan koordinasi dengan semua departemen yang akan terlibat. Dalam pelaksanaan kegiatan bakti sosial berupa sunatan masal gratis. kelengkapan administratif untuk para petugas kesehatan juga di siapkan sesuai dengan kebutuhan masing-masing departemen. Misalnya SIP bagi dokter umum maupun spesialis yang akan melakukan tindakan medik sunat dan surat tugas bagi tenaga lainya .serta sertifikat bagi semua tenaga yang terlibat dalam kegiatan bakti soial sunatan masal gratis.

Pada pelaksanaan kegiatan bakti sosial tersebut ada beberapa hal yang dipersiapkan yakni ketentuan yang terkait dengan bakti sosiall misalnya: kelengkapan admistrasi berupa kelengkapan status pasien bekerja sama dengan unit Rekam Medis, pemeriksaan penunjang lainya seperti laboratorium untuk cek darah, departemen house keping untuk membantu kebersihan dan perlengkapan lainnya, farmasi untuk menyediakan perlengkapan obat-obatan, unit kamar bedah untuk persiapan tempat dan alat-alat sunat.

\section{PEMBAHASAN}

\section{a. Ketentuan Hukum Tentang Patien Safety di RSPJ}

\section{Dasar Hukum}

1) Undang-Undang Dasar 1945

Undang-Undang Dasar 1945 menjamin semua warga negara mendapat pelayanan kesehatan secara sempurna. Tidak hanya mendapat pengobatan, tapi juga perlindungan atas potensi yang dapat menyebabkan timbulnya penyakit, seperti lingkungan sehat dan informasi kesehatan. Hal tersebut ditegaskan dalam pasal $28 \mathrm{H}$ ayat (1) yang menyatakan bahwa setiap orang berhak hidup sejahtera lahir batin, bertempat tinggal, dan mendapatkan lingkungan yang baik dan sehat serta berhak memperoleh pelayanan kesehatan.

2) Undang-Undang Kesehatan

Dalam Undang-undang Kesehatan Pasal 4 menyebutkan bahwa setiap orang berhak atas kesehatan, sementara pada Pasal 5 disebutkan hak kesehatan secara umum itu terdiri dari : (1) setiap orang mempunyai hak yang sama dalam memperoleh akses dalam sumber daya di bidang kesehatan, (2) setiap orang mempunyai hak dalam memperoleh pelayanan kesehatan yang aman, bermutu, dan terjangkau, (3) setiap orang berhak secara mandiri dan bertanggung jawab menentukan sendiri pelayanan kesehatan yang diperlukan bagi dirinya.

3) Undang-Undang Rumah Sakit

Pelaksanaan Patient Safety dalam segala bentuk pelayanan kesehatan wajib dijamin oleh penyelanggara pelayanan kesehatan tidak terlepas juga yang dilakukan oleh Rumah Sakit Premier Jatinegara, hal ini merujuk pada Undang-Undang rumah sakit Pasal 29 ayat (1) huruf b: bahwa Rumah Sakit berkewajiban untuk "memberi pelayanan kesehatan yang aman, bermutu, anti diskriminasi, dan efektif dengan mengutamakan kepentingan pasien sesuai dengan standar pelayanan rumah sakit".

\section{Tujuan Pengaturan Patient Safety di Rumah Sakit Premier Jatinegara}


Berdasarkan hasil penelitian dapat dianalisis bahwa tujuan dari pelaksanaan dan pengaturan Patient Safety antara lain :

1) Melaksanakan amanat Undang-Undang hal itu tercermin dalam pengaturan keselamatan pasien yang tertuang pada SK direktur NO.014/SK/DIR/RSPJ/VII/2012

2) Sebagai pelaksanaan pemenuhan hak pasien maka bisa ditarik kesimpulan bahwa kegiatan pelaksanaan bakti sosial oleh rumah sakit premier jatinegara merupakan amanat Undang-Undang tentang Patient safety merupakan suatu kewajiban yang dilaksnakan oleh setiap rumah sakit kemudain dari hasil wawancara juga diketahui bahwa kegiatan bakti sosial ini dilaksanakan setiap tahun oleh rumah sakit premier jatinegara dalam hal keawajiban melaksanakan amanat Undang-Undang.

3) Sebagai pelaksanaan kewajiban sebagai Rumah Sakit. disebutkan "bahwa setiap rumah sakit mempunyai kewajiban, memberikan pelayanan kesehatan yang aman, bermutu, antidiskriminasi, dan efektif dengan mengutamakan kepentingan pasien sesuai dengan standar pelayanan rumah sakit", serta "setiap rumah sakit mempunyai kewajiban: melaksanakan fungsi sosial antara lain dengan memberikan fasilitas pelayanan pasien tidak mampu/miskin, pelayanan gawat darurat tanpa uang muka, ambulan gratis, pelayanan korban bencana dan kejadian luar biasa, atau bakti sosial bagi misi kemanusiaan." Sementara itu dari hasil wawancara dengan manejer marketing diperoleh penjelasan bahwa Rumah Sakit Premier Jatinegara selalu melaksanakan kewajibannya yang diamanat undang-undang tersebut.

\section{Bentuk Pelaksanaan kegiatan Pateint Safety Rumah Sakit Premier Jatinegara}

Bentuk pelaksanaannya dilakukan dengan pembagian tahapan, yakni persiapan, proses pelaksanaan dan evaluasi atau pelaporan. Hal ini dilakukan berdasarkan SOP, yang merupakan salah satu bentuk peraturan internal di Rumah Sakit Premier Jatinegara.

Sebelum kegiatan bakti sosial dilakanakan ada beberapa yang harus disiapkan terkait kegiatan bakti sosial misalnya: Suarat Tugas, Surat ljin Prakter sebagai dokter, perlengkapan dan sebagainya. Sedangkan dalam proses kegiatan ada hal yang harus dipersiapkan misalnya saat dilakukan kegiatan tidak kekurangan dalam peralatan atau tidak terjadi kecelakaan misalnya saat bakti sosial dilaksanan. Sementara itu hal yang harus diperhatikan juga adalah bagaimana kegiatan itu berjalan sukses dan dilaporkan sebagai keberhasilan program kerja CSR bagi rumah sakit Premier jatinegara, setelah kegiatan bakti sosial selesai dilaksanakan tahap berikutnya adalah laporan dari ketua panitia terhadap manejer marketing dalam bentuk tulisan diantaranya : jumlah panitia, jumlah peserta bakti sosial serta peralatan yang terpakai dan perlatan yang masih ada, kemudian ketua panitia juga menginventarisir permasalahan yang timbul saat kegiatan berlangsung.

\section{b. Pengaturan CSR di Rumah Sakit Premier Jatinegara}

\section{Dasar Hukum}

\section{1) Undang-Undang Perseroan Terbatas}

Dalam Undang-Undang Perseroan Terbatas sebagaimana disebutkan dalam Pasal 1 butir 1, dalam undang-undang ini yang dimaksud dengan: "Perseroan Terbatas, yang selanjutnya disebut perseroan, adalah badan hukum yang merupakan persekutuan modal, didirikan berdasarkan perjanjian, melakukan kegiatan usaha dengan modal dasar yang seluruhnya terbagi dalam saham dan memenuhi persyaratan yang diterapkan dalam undang-undang ini serta peraturan pelaksanaanya."

Berdasarkan penjelasan dan ketentuan di atas maka rumah sakit premier jatinegara adalah merupakan usaha yang mempunayai dampak terhadap lingkungan dan 
diamatkan oleh undang-undang harus ikut ambil bagian terhadap kepedulian sosial lingkungan perusahaan untuk meningkatkan derjat hidup orang atau masyarakat terutama yang tidak mampu.

\section{2) Undang-Undang Penanaman Modal}

Dalam Pasal 15 disebutkan bahwa; "Setiap penanam modal berkewajiban :

a) menerapkan prinsip tata kelola perusahaan yang baik

b) melaksanakan tanggung jawab sosial perusahaan

c) membuat laporan tentang kegiatan penanaman modal dan menyampaikannya kepada Badan Koordinasi Penananman Modal

d) menghormati tradisi budaya masyarakat sekitar lokasi kegiatan usaha penanaman modal ;dan

e) mematuhi semua ketentuan peraturan perundang-undangan.

Selanjutnya di dalam penjelasan pasal ini disebutkan bahwa "yang dimaksud dengan "tanggung jawab perusahaan adalah tanggung jawab yang melekat pada setiap perusahaan penanaman modal untuk tetap menciptakan hubungan yang serasi, seimbang, dan sesuai dengan lingkungan, nilai, norma, dan budaya masyarakat setempat".

\section{3) Undang-Undang Rumah Sakit}

Pada ketentuan Pasal 29 ayat (1) huruf $f$ disebutkan bahwa: "setiap rumah sakit mempunyai kewajiban melaksanakan fungsi sosial antara lain dengan memberikan fasilitas pelayanan pasien tidak mampu/miskin, pelayanan gawat darurat tanpa uang muka, ambulan gratis, pelayanan korban bencana dan kejadian luar biasa, tau bakti sosial bagi pasien misi kemanusiaan".

\section{Bentuk Pengaturan CSR Pada Baksos Oleh RSPJ}

Berdasarkan Peraturan Pemerintah Republik Indonesia Nomor 47 tahun 2012 tentang Tanggung Jawab Sosial dan Lingkungan Perseroan Terbatas pasal 2 disebutkan "Setiap Perseroan selaku subjek hukum mempunyai tanggung jawab sosial dan lingkungan" dalam penjelasannya di sebutkan bahwa: menegaskan pada dasarnya setiap perseroan sebagai wujud kegiatan manusia dalam bidang usaha, secara moral mempunyai komitmen untuk bertanggung jawab atas tetap terciptanya hubungan perseroan yang serasi dan seimbang dengan lingkungan dan masyarakat setempat sesuai dengan nilai, norma, dan budaya masyarakaat tersebut.

\section{Bentuk Kegiatan CSR Pada Baksos Oleh RSPJ}

Kegiatan CSR pada Baksos oleh RSPJ, adalah dalam bentuk pelayanan kesehatan dan bantuan pembiayaan kesehatan bagi masyarakat tidak mampu di sekitar Rumah Sakit. Dalam aktivitas CSR perusahaan menyediakan dana atau sumber daya lainnya yang dimiliki perusahaan untuk meningkatkan kesadaran masyarakat terhadap suatu kegiatan sosial atau mendukung pengumpulan dana, partisipasi dari masyarakat. komunikasi persuasif dengan tujuan menciptakan kesadaran serta perhatian terhadap suatu masalah sosial, merupakan fokus utama dari kategori aktivitas CSR.

Dalam melaksanakan amanat Undang-Undang yang berkaitan dengan kegiatan CSR maka rumah sakit premier jatinegara menyelenggarakan beberapa kegiatan bakti sosial, berupa; pengobatan gratis, sunatan masal, operasi katarak, dan operasi bibir sumbing. Hal ini adalah merupakan perwujudan dari program CSR yang diamanatkan oleh Undang- 
Undang. Di sampimg itu berbagai bentuk kegiatan baksos tersebut adalah bentuk kepedulian perusahaan terhadap masyarakat tidak mampu di sekeliling perusahaan yang membutuhkan bantuan penggobatan.

\section{c. Faktor Yang Mempengaruhi Pelaksanaan Patient Safety Dalam Kegiatan Bakti Sosial di RSPJ}

\section{Faktor Yang Mendukung}

1) Karena merupakan amanat undang-undang dan peraturan pelaksanaa laiinya sehingga merupakan kewajiban bagi rumah sakit premier jatinegara untuk tunduk dan taat pada aturan tersebut.

2) Karena misi kepedulian terhadap kemanusiaan yang membutuhkan pertolongan.

3) Visi dari RS Premier Jatinegara “Rumah Sakit Premier Jatinegara berkomitmen untuk menjadi penyelenggara kesehatan terkemuka dengan memberikan hasil layanan yang berkualitas serta memastikan profitabilitas dalam jangka panjang. Sedangkan misi dari RS Premier Jatinegara adalah "memberikan pelayanan kesehatan bermutu dan memuaskan pelanggan serta mencapai kinerja yang diinginkan".

4) Dukungan sponsor untuk menbantu dalam hal pembiayaan operasi bibir sumbing.

\section{Sedangkan Faktor Yang Menghambat}

Dalam kegiatan bakti sosial tentunya juga dirasakan oleh rumah sakit premier jatinegara terutama dalam hal keterbatasan dana yang melibatkan tindakan medis khusus misalnya pada operasi bibir sumbing dan sejauh ini sponsor yang sudah menjalin kerja sama dengan pihak Rumah Sakit Premier Jatinegara adalah Stasiun Telivisi Swasta namaun demikian kegiatan ini tidak terlalu banyak dilakukan denga jumlah yang terbatas dikarenakan tindakan tersebut membutuhkan dana yang tidak sedikit .sehingga jangkauan untuk masalah pembiayaan terbatas, maka dari itu untuk menyelesaikan masalah tersebut di atas maka perlu bantuan atau sponsor dalam rangka membantu dengan masalaah pembiayaan.

\section{KESIMPULAN}

Dalam rangka melaksanakan amanat undang-undang tentang CSR maka rumah sakit premier jatinegara selalu mematuhinya, namun hal ini tidak bisa dilaksanakan dengan begitu saja, dikarenakan kegiatan CSR atau disebut juga dengan tanggung jawab perusahaan tidak semua bisa dilaksanakan dikarenakan terkendala soal biaya, oleh karena itu pelaksanaan CSR dirumah sakit Premier Jatinegara dalam rangka bakti sosial menjamin keselamatan Patient Safety merupakan upaya wajib dan harus dilaksanakan sesuai dengan amanat Undang-Undang.

Sementara itu dari uraian diatas maka dapat disimpulkan sebagai berikut :

a. Keselamatan pasien (patient safety) rumah sakit adalah suatu sistem dimana rumah sakit membuat asuhan pasien lebih aman. Sistem tersebut meliputi : assessmen risiko, identifikasi dan pengelolaan hal yang berhubungan dengan risiko pasien, pelaporan dan analisis insiden, kemampuan belajar dari insiden dan tindak lanjutnya serta implementasi solusi untuk meminimalkan timbulnya risiko. Sistem tersebut diharapkan dapat mencegah terjadinya cedera yang disebabkan oleh kesalahan akibat melaksanakan suatu tindakan atau tidak melakukan tindakan yang seharusnya dilakukan.

Ada beberapa ketentuan hukum pelaksanaan Patient Safety di Rumah Sakit yang harus diketahui adalah sebagai berikut : 
1. Undang-Undang Nomor 39 tahun 1999 tentang Hak Asasi Manusia.

2. Undang-Undang Republik Indonesia Nomor 29 Tahun 2004 Tentang Praktik Kedokteran

3. Undang-Undang Republik Indonesia Nomor 36 Tahun 2009 Tentang Kesehatan

4. Undang-Undang Republik Indonesia Nomor 44 Tahun 2009 Tentang Rumah sakit

5. Peraturan Menteri Kesehatan Nomor 1691/MENKES/PER/2011 Tentang Keselamatan Pasien Rumah Sakit

Dengan mengacu kepada ketentuan hukum yang mengatur pelaksanaan Keselamatan Pasien, maka dapat dipastikan bahwa Keselamatan Pasien merupakan hak setiap orang yang dilindungi oleh konstitusi UUD 1945 serta peraturan perundangan lainnya. Karena itu Rumah sakit sebagai penyelenggara pelayanan kesehatan wajib melaksanakan patient safety sebagai wujud tanggung jawab rumah sakit dalam menjalankan konstitusi dan menjalankan kewajibannya sebagai penyelenggara kesehatan yang sudah diatur dalam peraturan perundangan-undangan.

b. Kebijakan Pelaksanaan Patient Safety melalui Manajemen rumah sakit premier Jatinegara diatur dalam :

1. Hospital by Law dan Medical staf by law RS Premier Jatinegara

2. Surat Keputusan Direktur Nomor 014/SK/DIR/RSJP/VII/2012 tentang Kebijakan Keselamatan Pasien RS Premier Jatinegara.

c. Pelaksanaan Patient Safety di RS Premier Jatinegara mengacu kepada standar akreditasi Joint Commission International $(\mathrm{JCl})$ dan Akreditasi KARS. Kedua sertifikasi tersebut berupaya melaksanakan patient safety sebagai mutu pelayanan kesehatan. Ini merupakan wujud tanggung jawab RS Premier Jatinegara untuk melaksanakan fungsi sosial dan tanggung jawabnya sebagai penyelanggaraan kesehatan. Program CRS sebagai salah satu tanggung jawab sosial perusahaan dan dalam melaksanakan pelayananan yang ada sudah seharunya melaksanakan patient safety sesuai dengan standar elemen dari akreditasi $\mathrm{JCI}$ dan akreditasi Komite Akreditasi Rumah Sakit. Dari hasil penelitian ini dapat disimpulkan bahwa pelaksanaan bakti sosial ini dilakukan dalam rangka Patient Safety, dimana setiap pelaksanaan dari standar yang dilakukan untuk dapat mencegah terjadinya kejadian yang tidak diinginkan (KTD)

\section{SARAN}

a. Saran untuk Rumah sakit Premier jatinegara

Membuat kebijakan intern RS tentang Pelaksanaan Baksos yang memeperhatikan Patient Safety

b. Saran untuk Pemerintah

Melakukan pengawasan terhdap rumah sakit terkait dengan pelaksanaan bakti sosial apakah sudah sesuai dengan ketentuan hukum Patient Safety.

c. Saran untuk Masyarakat

Untuk mendapatkan informasi tentang hak-haknya sebagai pasien bahwa pelayanan yang diberikan dalam kegiatan Baksos harus berpedoman pada Patient Safety.

d. Saran untuk organisasi profesi

Dapat diperhatikan perlindungan hukum terhadap tenaga medis dalam pelaksanaan Bakti Sosial.

\section{DAFTAR PUSTAKA}


Azwar Azrul, 1996, Pengantar Administrasi Kesehatan, Jakarta: Bina Putra Aksara.

Acmad Ali, Menguak Tabir Hukum, Ghalia Indonesi

Bambang Sunggono, 2007, Metodologi Penelitian Hukum, Rajagrafindo Persada.

Bahder Johan Nasution, 2005, Hukum Kesehatan Pertanggungjawaban Dokter, Jakarta: Rineka Cipta.

Bambang Sulistiyo, Wangi Sebelum Ada Peraturan,Gatra.No.44,Tahun XII,20 september 2006

Endang Wahyati Yustina, 2007, Mengenal Hukum Rumah Sakit, Jakarta: Keni Media.

Edi Suharto, 2010, CSR dan COMDEV, investasi Kreatif Perusahaan di Era Globalisasi, Bandung Alfabeta.

Hendrik Budi Untung, 2008, Corporate Social Responsubility, Jakarta, Sinar Grafika.

Juniarso Ridwan dan Acmad Sodik Sudrajat, 2009, Hukum Administrasi Negara dan kebijakan Pelayanan Publik, Bandung, Nuansa.

Nazir M, 1985, Metode Penelitian, Jakarta: Ghalia Indonesia.

Rianto Adi, 2005, Metodologi Penelitian Soaial dan Hukum :Granit Jakarta.

Ridwan Khairaandy, 2009, Perseroan Terbatas, Yogjakarta, total Media.

Sutan Remy Sjahdeini, Corporate Social Responsibility, jurnal Hukum Bisnis, Volume 26-No, 3 Tahun 2007.

Sukandarrumidi, 2012, Corporate Social Responsibility,usaha meredam unjuk akibat gangguan lingkungan, Yogjakarta, Bajawa Press.

Tutik, Titik T dan Febriana, S., 2010, Perlindungan Hukum Bagi Pasien, Jakarta: Prestasi Pustaka.

Wila Chandrawila Supriadi, 2001, Hukum kedokteran, Bandung: C.V. Mandar Maju.

WiLLiam N.Dunn, 1999, Pengantar Analisis Kebijakan Publik edisi ke Dua,Yogjakarta, Gajah mada University Press.

Soerjono Soekanto, 1990, Segi-segi Hukum Dan Kewajiban Pasien, Mandar maju.

Freddy Tengker, 2007, Hak Pasien, Mandar Maju, Bandung.

Mulhadi, 2010, Hukum Kesehatan, Ghalia Indonesia.

Abdulkadis Muhammad, 1998, Hukum Perusahan Indonesia, Bandar Lampung.

Soekijo Notoatmodjo, 2002, Metodologi Penelitian Kesehatan, Jakarta, pertama.

F.Tengker, 1991, Pelayanan kesehatan dan Pendemokrasian, Nova, Bandung.

Soekjidjo Notoatmodjo, 2007, Kesehatan Masyarakat, Rineka Cipta, Jakarta.

Internet:

www.ppjk.depkes.gp.id/index.php?option=...task Tanggal 27 desember 2012

www.ppjk.depkes.go.id/index.php?option=com...task Tanggal 27 Desember 2012

www:http://pancurbatu.wordpress,Jamkesmas Tanggal 27 Desember 2012

Berita resmi statisktik, Badan Pusat Statistik, nomor 06/01/Th.XVI,2 Januari 2013

\section{Perundang-Undangan}

Undang-Undang Republik Indonesia Nomor 39 Tahun 1999 tentang Hak Asasi Manusia. 
Undang-Undang Republik Indonesia Nomor 29 Tahun 2004 Tentang Praktek Kedokteran

Undang-undang Republik Indonesia Nomor 25 Tahun 2007 Tentang Penanaman Modal.

Undang-undang Republik Indonesia Nomor 40 Tahun 2007 tentang Perseroan Terbatas.

Undang-Undang Republik Indonesia Nomor 44 Tahun 2009 Tentang Rumah sakit

Undang-undang Republik Indonesia Nomor 36 Tahun 2009 Tentang kesehatan

Peraturan Menteri Kesehatan Nomor 1691/MENKES/PER/2011 Tentang Keselamatan Pasien Rumah Sakit

Peraturan pemerintah Republik Indonesia Nomor 47 Tahun 2012 Tentang Tanggung Jawab Dan Lingkungan Perseroan Terbatas. 